\title{
EVALUASI DALAM PENDIDIKAN ISLAM
}

\author{
Bahrum Subagiya \\ Universitas Ibn Khaldun Bogor \\ bahrum.subagiya@uika-bogor.ac.id
}

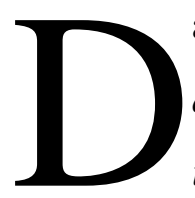

alam bahasa Arab istilah evaluasi dikenal dengan istilah taqwim atau taqyim, ${ }^{1}$ serta qayyim yaitu jamak dari qimah. ${ }^{2}$ Athiyah Al-Abrasi menggunakan istilah lain, yaitu imtihan jamak dari imtihanat. ${ }^{3}$ Sementara Abudin Nata menambahkan dengan istilah khataman yang dalam bahasa arab dikenan dengan istilah taqyim khatami yang berati evaluasi sumatif. ${ }^{4}$

Pada dasarnya evaluasi adalah sebuah kegiatan mengukur dan menilai, mengukur berarti membandingkan sesuatu dengan satu ukuran, yang mana pengukuran di sini lebih bersifat kuantitatif, sedangkan menilai berarti mengambil suatu keputusan terhadap sesuatu dengan ukuran baik buruk, sehingga penilaiaan disini bersifat kualitatif. Di dalam istilah asingnya, pengukuran adalah measurement, sedangkan penilaian adalah evaluation. Dari kata evaluation inilah diperoleh kata indonesia evaluasi yang berarti menilai yang diawali dengan mengukur terlebih dahulu. ${ }^{5}$

Meskipun kini evaluasi memiliki makna yang lebih luas, namun pada awalnya pengertian evaluasi pendidikan selalu dikaitkan dengan hasil prestasi belajar siswa. Definisi ini pertama kali dikembangkan oleh Ralph Tyler, yang mengatakan bahwa evaluasi merupakan sebuah proses pengumpulan data untuk menentukan sejauh mana, dalam hal apa, dan bagaimana tujuan pendidikan sudah tercapai. Jika belum, bagaimana yang belum dan apa sebabnya. ${ }^{6}$ Definisi ini sepertinya serupa dengan definisi yang diajukan oleh Ahmad Tafsir, bahwa pada hakikatnya evaluasi lebih bersangkutan langsung dengan tujuan awal yang telah dirumuskan. ${ }^{7}$ Definisi yang tidak jauh berbeda juga dikemukakan dari Hasan Langgulung mendifinisikan evaluasi sebagai

\footnotetext{
${ }^{1}$ Muhammad Ali Al-Hulli, Qamus Al-Tarbiyah, Beirut: Dar Al-Ilm li Al-Malayin, 1981, hlm. 165.

${ }^{2}$ Abdul Rayid Abdul Aziz, Turuq Al-Tadris Al-Tarbiyah Al-Islamiyah, Kuwait : Wakalat Al-Mathbu'at, 1982,hlm. 52.

${ }_{3}^{3}$ Athiyah Al-Abrasi, Ruh Al-Tarbiyah Wa Ta'lim, Kairo: Dar lhya Al-kutub Al-Arabiyah, hlm. 360.

${ }_{4}$ Abudin Nata, Filsafat Pendidikan, Jakarta : Logos Wacana Ilmu, 1997, hlm. 131.

5 Suharsimi Arikunto, Dasar-dasar Evaluasi Pendidikan, Jakarta : Bumi Aksara, 2009, hlm. 3.

${ }^{6}$ Ibid.

7 Ahmad Tafsir, Ilmu Pendidikan Dalam Perspektif Islam, hlm.73.
} 
sebuah cara penilaian untuk mengukur dan menilai kurikulum dan hasil pembelajaran yang telah dirancang dalam kurikulum. ${ }^{8}$

Definisi yang lebih luas lagi dikemukakan oleh dua orang ahli lain, yakni Cronbach dan Stufflebean. Keduanya menambahkan definisi tersebut dengan menyatakan bahwa evaluasi bukan sekedar mengukur sejauh mana tujuan telah tercapai, tetapi juga digunakan untuk membuat keputusan (judgement). ${ }^{9}$

Adapun yang dimaksud dengan evaluasi pendidikan di dalam tulisan ini lebih ditekankan pada sebuah penilaian untuk mengukur dan menilai keberhasilan dalam mendidik manusia.

Jika perjalanan pendidikan berjalan sesuai dengan apa yang telah di tetapkan oleh ajaran Islam dan berhasil melewati penghalang-penghalang-nya, maka akan melahirkan manusia pari purna, sehat lahir batin, bahagia dunia dan akhirat. Menurut Muhammad Anas Karzon keberhasilan dalam pendidikan akan membuahkan dua kebahagiaan sekaligus, yaitu sa'adah aldunya, dan sa'adah al-akhirah. ${ }^{10}$

1. Kebahagiaan duniawi (sa'adah al-dunya).

a) Kebagahagiaan individu

1) Merasakan manisnya iman (khalawah al-iman), yakni seorang mukmin yang menyucikan jiwanya dengan melakukan ketaatan kepada Allah dan bersegera meraih berbagai kebaikan, serta waspada akan berbagai kejahatan akan merasakan buah manisnya iman, hal itu sebagai mana dikatakan oleh Ibn Abbas: "Sungguh, kebaikan itu menyebabkan sinar di dalam hati, cahaya pada wajah, kekuatan pada tubuh, keluasan rizqi, dan cinta di dalam hati manusia. Sebaliknya, kejahatan itu menyebabkan kegelapan dalam hati, wajahnya tidak bercahaya, kelemahan pada badan, kesempitan kepada rizqi, dan kebencian di hati manusia. Manisnya iman ini dapat diraih seseorang setelah melakukan tiga hal". 1, Hendaknya Allah dan Rasulnya lebih dicintai dari yang lainnya. 2, Hendaknya mencintai sesuatu hanya atas dasar karena Allah. 3, Hendaknya benci terhadap kekufuran sebagaimana ia benci jika dilemparkan ke neraka.

\footnotetext{
${ }^{8}$ Hasan Langgulung, Peralihan Paradigma Dalam Islam Dan Sains Sosial, hlm.241.

9 Suharsimi Arikunto, Dasar-dasar Evaluasi Pendidikan, Ibid.

${ }^{10}$ Anas Ahmad karzun, Tazkiatun Nafs, hlm. 329.
} 
2) Rela berkorban baik jiwa maupun harta dijalan Allah ( badzl al-nafs). yakni saat jiwa telah meningkat dengan penyucian jiwa dan hati telah bersih dari keterikatan dengan dunia, dan telah merasakan manisnya iman, serta cinta sejati kepada Allah dan Rasulnya, maka hal itu akan membangkitkan jiwa untuk rela berkorban demi menggapai cinta Allah Subhanahu wa Ta'ala.

3) Kemuliaan jiwa (izzah al-nafs), yakni jiwa yang telah disucikan maka ia tidak akan tercampur oleh kehinaan, jika demikian kemuliaan jiwa akan tercapai. Hal itu berdasarkan firman Allah surat Fathir ayat 10 dan surat Annisa ayat 139. Ayat tersebut menunjukan bahwa seorang mukmin yang shaleh yang jiwanya suci dengan taat kepada Allah, maka Allah akan memberinya kemuliaan di dunia dan di Akhirat. Sebaliknya, seorang yang kafir yang mengotori jiwanya dengan kekufuran, maka Allah akan menimpakan baginya kehinaan dan kelemahan.

4) Jiwa akan menjadi kaya (ghina al-nafs), yakni jiwa yang bersih akan selalu merasa kaya karena telah terbebas dari kotornya kerakusan duniawi dan angkara ketamakan. Hali itu sebagai mana sabda Rasullulah Shalallahu 'Alaihi wa Sallam: "Kekayaan itu bukanlah dengan banyaknya harta, namun kekayaan itu adalah kekayaan jiwa”. Dari hadits tersebut secara jelas menggambarkan bahwa hakikat kekayaan bukanlah terletak pada kekayaan hartanya akan tetapi terletak pada kekayaan jiwa.

5) Ketenangan jiwa (sakinah al-nafs), yakni jika pondasi aqidah untuk penyucian jiwa telah tertanam didasar jiwa maka akan membuahkan sebuah ketenangan yang hakiki. Hal itu berdasarkan firman Allah surat Al-Ra'd ayat 28. Dari ayat tersebut, dijelaskan bahwa asal ketentraman adalah berangkat dari ketenangan, kemantapan dan kewibawaan yang di turunkan oleh Allah ke dalam hati hambanya saat mereka tulus menyebut nama Allah. ketenangan juga merupakan kehidupan hati dari pancaran cahaya keimanan setelah seorang hamba berupaya mendekatkan diri kepada Allah Subhanahu wa Ta'ala.

6) Membuahkan cita-cita yang tinggi (sumuw al-nafs), yakni setiap kali jiwa memperkuat penyuciannya dan hati menyempurnakan kehidupan, saat itu cita-citanya meninggi dan kemauannya menguat karena kehendak dan cinta akan mengikuti perasaan terhadap keinginan yang di cintainya, orang yang hatinya di penuhi oleh cinta kepada tuhannya, kehendaknya menguat untuk meraih ridha nya, jiwanya akan naik dari nilai-nilai 
kerendahan. Inilah sebagaimana diisyaratkan oleh Allah dalam firmannya surat AsSams ayat 9-10.

7) Akhlak yang mulia (khusn al-kuluq), yakni pensucian jiwa akan membuahkan akhlak mulia karena akhlak hanya muncul dari jiwa yang suci.

8) Kehidupan yang lebih baik (al-hayah al-thayyibah), yakni seseorang yang jiwanya suci, ia akan berjalan di muka bumi ini dengan cahaya, cahaya itu merupakan pancaran dari keimananya sehingga kehidupannya akan terarah, mendapatkan petunjuk dan jauh dari kesesatan. Hal itu sebagai mana firman Allah dalam surat Taha ayat 123-126 dan firman Allah surat An-Nahl ayat 97.

9) Hikmah dan firasat (al-hikmah wa al-firasah). Hikmah adalah meletakan sesuatu pada tempatnya dan melihat sesuatu dengan pandangan yang jauh dengan pikiran yang jernih yang semua itu merupakan hasil dari kebersihan jiwa seseorang. Ia adalah cahaya yang di berikan oleh Allah ke dalam hati seorang hamba yang bersih jiwanya sehingga ia mampu membedakan antara yang haq dan yang batil, antara petunjuk dan kesesatan, antara bahaya dan manfaat, antara kesempurnaan dan kekurangan. Ia juga akan mampu melihat peringkat amal, mana pendapat yang kuat dan mana pendapat yang kurang kuat. Oleh karena itu semakin seseorang hamba banyak berbuat kebaikan dan maksimal dalam mensucikan jiwanya, maka peluang untuk mendapatkan cahaya hikmah akan semakin besar. Tidak hanya itu, ia juga akan mendapat firasat mengenai dirinya dan orang lain dengan lebih cepat. Hal itu sebagaimana firman Allah surat Al-Baqarah ayat 269.

10) Kesehatan tubuh (shihah al-jasad), yakni jiwa yang sehat, akan menjadikan fisik menjadi lebih sehat, karena pada dasarnya penyakit fisik ditimbulkan oleh guncanganguncangan fisikologis. Tidak diragukan lagi bahwa guncangan fisikologis tersebut bermula dari kecemasan-kecemasan, ketergantungan materi, ambisi yang melampaui batas dan depresi kehidupan. Sedangkan orang yang beriman, jiwanya akan selalu dipenuhi oleh cinta kepada Allah dan Rasulnya sehingga ia mampu merasakan manisnya iman dengan demikian muncullah kebahagiaan hakiki pada dirinya, jiwanya tenang, hidupnya pun merasakan ketenangan. Itu semua berpengaruh positif terhadap kesehatan fisiknya. Imam Ibn Rajab berkata “ Barang siapa yang menjaga Allah di waktu muda dan kuat, maka Allah akan menjaganya di saat tua dan lemah, memberinya kenikmatan 
pendengaran dan penglihatan, kekuatan, kemampuan dan akal. Lebih lanjut Ibn Rajab menceritakan bahwa ada seorang ulama yang usianya lebih dari seratus tahun, ia diberi kenikmatan berupa kekuatan fisik dan akal. Suatu hari ia meloncat dengan loncatan yang luar bisa, maka orang banyak yang melihatnya mengingatkan akan hal itu, lalu ia berkata "Ketika aku masih muda aku menjaga tubuhku dari maksiat, maka Allah pun menjaga diriku saat aku telah tua. ${ }^{11}$

\section{b) Kebahagian masyarakat}

Kebahagiaan masyarakat pada intinya bersumber dari kebahagiaan individu-individunya yang bersih jiwanya dengan taat kepada tuhannya. Jiwa yang bersih akan memancarkan cahaya iman. Cahaya inilah yang menyinari seluruh masyarakat dan mengusir kegelapan. Dengan jiwa-jiwa yang bersih, akhlak terpuji akan mendominasi dan tersebarlah kasih sayang dan cinta kasih. Dari akhlak inilah akan memunculkan kehidupan masyarakat yang adil dan ketentraman umum. Berkata penyair:

$$
\text { و إنما الأمم الأخلاق ما بقيت \# فإن هم ذهبت أخلاقهم ذهبوا }
$$

"Sesungguhnya kejayaan suatu umat ditentukan oleh akhlaknya, jika hilang dari mereka akhlak, hilang pulalah peradabannya." ${ }^{\prime 2}$

Kebahagiaan masyarakat tersebut terlihat dalam beberapa hal berikut ini:

a. Tersebarnya ukhuwah dan kasih sayang, yakni jika individu-individu suatu masyarakat berkomitmen pada agama mereka dan antusias dalam mensucikan jiwa, maka noda-noda dendam dan egoisme individual akan sirna. dengan demikian akan tumbuh ikatan persaudaraan dan cinta di antara mereka, saling menghormati, empat terhadap sesama dan tulus dalam berbagi kebajikan. Hal itu berdasarkan hadits nabi Muhammad Shalallahu 'Alaihi wa Sallam "Demi jiwaku yang ada ditangannya kalian tidak akan masuk surga hingga kalian beriman, kalian tidak akan beriman hingga saling mencintai. Inginkan kalian kutunjukan sesuatu yang jika kalian melakukannnya maka kalian akan saling mencintai? sebarkan lah salam diantara kalian.”

${ }_{11}$ Ibn Rajab, Ja'mi Al-Ulum Wa Al-Hikam, HIm. 163.

${ }_{12}$ Thaha Ali Husain, Asalib Tadris Al-Tarbiyah Al-Islamiyah, Mesir: Dar Al-Syuruq, 2003, hlm.151 
b. Munculnya sikap tanggungjawab sosial, yakni kesucian jiwa masyarakat akan berdampak posutif terhadap sikap yanggung jawab sosial. Hal itu sebagai mana terdapat dalam firman Allah QS. Al-Maidah ayat 2 dan surat Al-Fath ayat 9.

c. Munculnya rasa aman dan tercegahnya kriminalitas, yakni jika jiwa individual masyarakat telah lurus dalam ketaatan kepada Allah maka ia akan memenuhi hak dan kewajibanya baik yang bersifat hablumminallah dan hablumminanas dengan demikian keamanan masyarakat akan terwujud dan sirnalah kriminalitas di tengah-tengah mereka. Karena jiwa yang dipenuhi keimanan akan mewujudkan keamanan dan menghindarkan pelakunya dari perbuatan keji dan munkar. hal itu sebagaimana firman Allah surat An-Nahl ayat 112 dan Ar-Rum ayat 141.

d. Terwujudnya masyarakat yang bermartabat yakni kesalehan individual masyarakat akan menbuahkan izzah pada tatanan masyarakat. Inlah janji Allah yang termaktub dalam surat An-Nur ayat 55 dan surat muhammad ayat 7.

2. Kebahagiaan di Akhirat

Kebahagian akhirat ini merupakan janji Allah yang pasti, yaitu berupa kenikmatan yang kekal, hidup dalam surga yang abadi, melihat wajah Allah yang maha tinggi lagi maha mulia. Hal itu berdasarkan firman Allah surat Al-Qasas ayat 83, dan surat Al-Isra ayat 19. Kebahagiaan akhirat ini dapat terlihat dalam hal-hal berikut.

a. Kebahagiaan menjelang kematian, yakni jiwa yang sehat menjelang ajalnya akan disambut kabar gembira dari Allah Subhanahu wa Ta'ala, hal tersebut berdasarkan firman Allah surat Al-Fazr ayat 27-90 dan surat Al-Fushilat ayat 30.

b. Kebahagiaan di alam barzah, yakni seseorang yang bersih jiwanya akan diberikan kenikmatan dalam kuburnya dan diselamatkan dari fitnah-fitnah di dalamnya. Hal itu berdasarkan hadits Barro bin Aziz.

c. Kebahagian di padang mahsyar, hisab dan sirath.

d. Kebahagiaan masuk syurga dan melihat wajah Allah. ${ }^{13}$ 


\section{DAFTAR PUSTAKA}

Abdul Rayid Abdul Aziz, Turuq Al-Tadris Al-Tarbiyah Al-Islamiyah, Kuwait : Wakalat Al-Mathbu'at, 1982

Abudin Nata, Filsafat Pendidikan, Jakarta : Logos Wacana Ilmu, 1997

Ahmad Tafsir, Ilmu Pendidikan Dalam Perspektif Islam

Anas Ahmad karzun, Tazkiatun Nafs

Athiyah Al-Abrasi, Ruh Al-Tarbiyah Wa Ta 'lim, Kairo: Dar Ihya Al-kutub Al-Arabiyah

Hasan Langgulung, Peralihan Paradigma Dalam Islam Dan Sains Sosial

Ibn Rajab, Ja'mi Al-Ulum Wa Al-Hikam,

Muhammad Ali Al-Hulli, Qamus Al-Tarbiyah, Beirut: Dar Al-Ilm li Al-Malayin, 1981

Suharsimi Arikunto, Dasar-dasar Evaluasi Pendidikan, Jakarta : Bumi Aksara, 2009

Thaha Ali Husain, Asalib Tadris Al-Tarbiyah Al-Islamiyah, Mesir: Dar Al-Syuruq, 2003 